\title{
ANALISA PERHITUNGAN DAN PEMILIHAN LOAD CELL PADA RANCANG BANGUN ALAT UJI TARIK KAPASITAS 3 TON
}

\author{
JAMALUDIN \\ Program Studi Teknik Mesin, Fakultas Teknik, Universitas Muhammadiyah Tangerang \\ J1. Perintis Kemerdekaan I/33 Cikokol-Tangerang \\ Email : jamaludinpermana14@yahoo.com
}

\begin{abstract}
ABSTRAK
Seiring dengan kemajuan ilmu pengetahuan dan teknologi yang menjadi pusat perhatian dunia. Maka manusia dituntut untuk menciptakan peralatan-peralatan canggih untuk teknologi muktahir. Baik itu dalam bidang bisnis, perdagangan, kesehatan, militer, pendidikan, komunikasi dan budaya maupun bidang-bidang lainnya. Maka teknologi ini membawa perubahan pada peralatan-peralatan yang dulunya bekerja secara analog mulai dikembangkan secara digital, dan bahkan yang bekerjanya secara manual sekarang banyak dikembangkan secara otomatis, seperti kamera digital, handycam, dan sebagainya, dalam pembacaan pengukuran juga sudah dikembangkan ke dalam teknik digital. Contohnya perangkat Load Cell. Dan keuntungan menggunakan Load Cell adalah untuk mempermudah dalam pembacaan data untuk meminimalkan kesalahan dalam pembacaan data yang disebabkan adanya human error.Pada pemilihan Load Cell bertujuan untuk memilih kecocokan dalam membuat rancang bangun alat uji tarik kapasitas 3 ton, dimana dalam pemilihan ini kami memilih jenis load cell " $S$ " karna alat yang kita rancang adalah uji tarik bukan uji tekan. Dengan kapasitas load cell 5 ton. Untuk membuat jarak aman dalam pengujian specimen ST41. Load Cell menggunakan system perangkat elektronik pengolahan data yang menjadi sebuah kurva tegangan regangan. Data-data yang diperoleh tersebut berupa besarnya pembebanan hasil dari pengujian specimen ST41.
\end{abstract}

Kata Kunci : alat uji tarik, specimen ST41, load cell, jenis load cell, kerusakan yang terjadi di load cell

\section{PENDAhULUAN}

Seiring dengan kemajuan ilmu pengetahuan dan teknologi yang menjadi pusat perhatian dunia. Maka manusia dituntut untuk menciptakan peralatan-peralatan canggih untuk teknologi muktahir. Baik itu dalam bidang bisnis, perdagangan, kesehatan, militer, pendidikan, komunikasi dan budaya maupun bidang-bidang lainnya.

Maka teknologi ini membawa perubahan pada peralatan-peralatan yang dulunya bekerja secara analog mulai dikembangkan secara digital, dan bahkan yang bekerjanya secara manual sekarang banyak di kembangkan secara otomatis, seperti kamera digital, handycam, dan sebagainya, dalam pembacaan pengukuran juga sudah dikembangkan ke dalam teknik digital. Contohnya perangkat Load Cell . Hal ini untuk mempermudahkan dalam pembacaan data dan meminimalkan kesalahan pembaca data yang di sebabkan adanya human error. Load Cell merupakan tranduser yang digunakan untuk mengubah deformasi tekanan menjadi sinyal listrik. Adalah salah satu perangkat elektronik yang digunakan sebagai perangkat tambahan pada mesin uji tarik.

Load Cell menggunakan system perangkat elektronik pengolahan data yang menjadi sebuah kurva tegangan regangan. Data-data yang diperoleh tersebut berupa besarnya pembebanan, besarnya perpanjangan dan perubahan luas penampang yang terjadi pada benda kerja. Oleh karena itu bagaimanapun faktor manusia sangat dominan untuk memperoleh hasil dari pengujian ini. ( Material ST-41). Pembebanan dan perubahan panjang benda kerja inilah yang nantinya akan dikonversikan ke dalam kurva uji tarik. Oleh karena itu penulis akan membahas 
masalah yang di hadapi oleh sebuah industri atau pribadi untuk menentukan material dasar logam. dan mencoba membahas masalah ini dalam penulisan tugas akhir yang berjudul : " Analisis Pemilihan Load Cell Pada Rancang Bangun Alat Uji Tarik Kapasitas 3 Ton LAB TM-18"

\section{LANDASAN TEORI}

\subsection{PENGERTIAN LOAD CELL}

Load cell berupa sel tahanan resistor yang melekat pada bidang keras (alumunium atau besi) yang akan berubah-ubah nilainya jika bidang tersebut mengalami tekanan atau load. Oleh suatu beban, berupa nilai tahanan yang diukur dalam satuan ohm. Jika diberi tegangan voltase input dan output akan menghasilkan voltase tegangan yang berpariatif, voltase tersebut yang nantinya akan dikelola oleh load indikator atau timbangan elektronik sebagai berat angka kilogram.

\subsection{JENIS-JENIS LOAD CELL}

a) Load cell Shear Beam biasanya jenis load cell ini digunakan untuk floor scale.

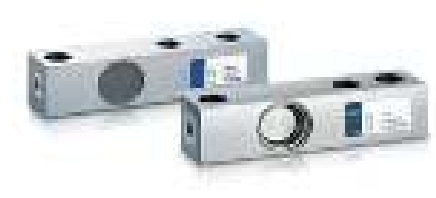

Gambar 2.1 Load Cell Shear Beam

(Sumber : www.anakristi40.com)

b) Load cell singel Point sedangkan untuk load cell ini dipasang pada bagian tengah platform timbangan bench scale.

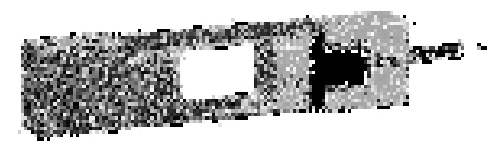

Gambar 2.2 Load Cell Single Point

\section{(Sumber : www.anakristi40.com)}

c) Load cell " $S$ " sesuai dengan namanya load cell ini berbentuk seperti hurup " $S$ ',

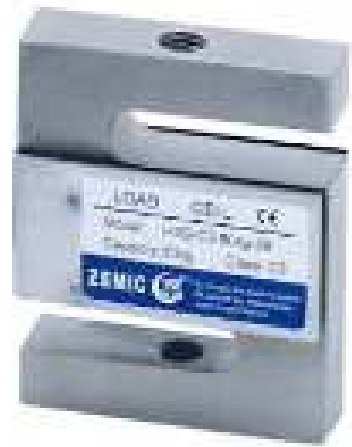

Gambar 2.3 Load Cell ' $S$ ',

(Sumber : www.anakristi40.com)

d) Load cell Compress pada umumnya jenis load cell ini digunakan untuk mengukur muatan truck.

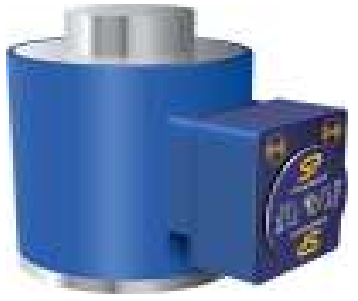

Gambar 2.4 Load Cell Compress (Sumber : www.anakristi40.com)

e) Load cell Double Ended load cell ini juga bisa digunakan untuk timbangan truck.

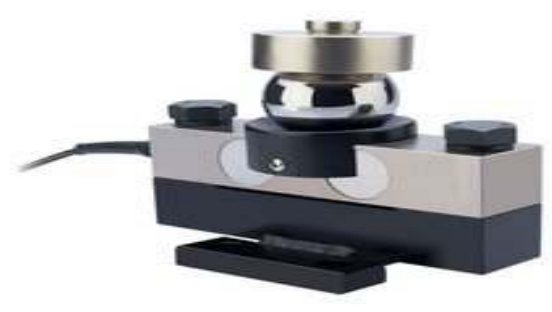

Gambar 2.5 Load Cell Double Ended (Sumber : www.anakristi40.com)

\subsection{MELAKUKAN UJI TARIK}

Uji tarik adalah suatu metode yang digunakan untuk menguji kekuaatan suatu bahan atau material dengan cara memberi 
beban gaya yang sesumbu, hasil yang yang didapat dari pengujian tarik sangat penting untuk rekayasa teknik dan desain produk karena menghasilkan data kekuatan material. Pengujian uji tarik digunakan untuk mengukur ketahanan suatu material terhadap gaya statis yang diberikan secara lambat..

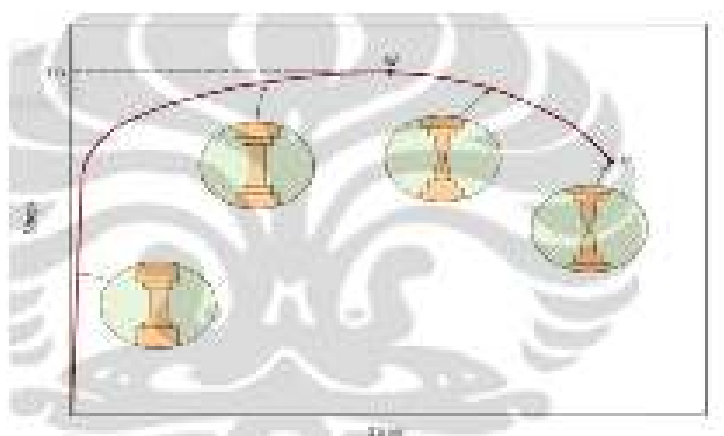

Gambar 2.6 Pemberian Beban Pada Spesimen

(Sumber : Penelitian Pembuatan Alat Uji Tarik Material, 2012)

\subsection{ALAT UJI TARIK (RANCANG BANGUN)}

Alat uji tarik merupakan suatu alat uji mekanik untuk mengetahui beban terhadap gaya tarik. Alat uji tarik memanfaatkan Load Cell sebagai media uji tarik dalam timbangan. Diukur melalui load cell. Dan diproses melalui PLC dan ditampilkan melalui load indikator, dalam Pengujian material didunia industri tidaklah asing, hal ini dasar dalam pembuatan suatu alat harus mengetahui kekuatan material. Maka keuntungan menggunakan sistem load Cell pada alat uji tarik mampu menghasilkan tingkat keakurasian yang besar, konstruksi sederhana, dan proses pembuatan yang terjangkau. Berikut adalah cara kerja alat uji tarik secara singkat. Hidupkan mesin, motor menggerakan pompa yang selanjutnya pompa menyuplai fluida bertekanan kedalam silinder melalui pipa. Selanjutnya piston rod akan maju kedepan karena ada dorongan dari piston yang saling menyatu. Piston rod akan menarik material yang sudah terpasang pada ragum, sesudah material putus Load cell akan mengirim data ke PLC dan akan menampilkan hasil yang berupa grafik pada monitor dan mesin pun secara otomatis akan berhenti. Berikut ini adalah contoh alat rancang bangun alat uji tarik kapasitas 3 ton .

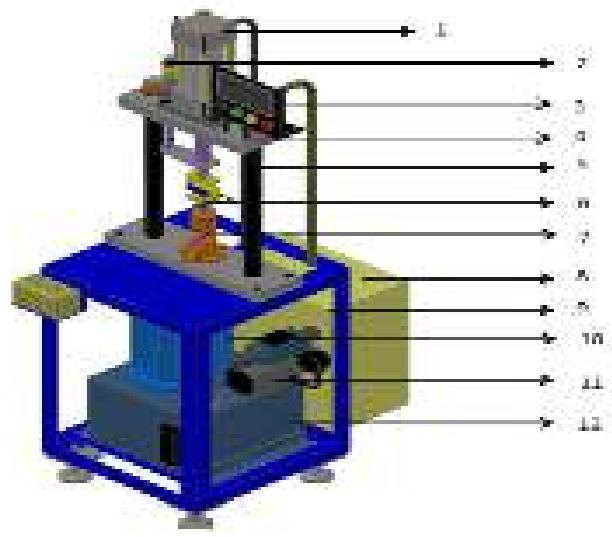

Gambar 2.7 Alat Uji Tarik

\section{METODE PENELITIAN}

Sebagai pelengkap pembahasan ini maka diperlukannya adanya data atau informasi baik dari dalam perusahaan maupun dari luar perusahaan. Penulis memperoleh data yang berhubungan dengan menggunakan metode sebagai berikut.

\section{a. Observasi}

Yaitu suatu bentuk penelitian yang dilakukan penulis dengan pengamatan baik secara berhadapan langsung maupun secara tidak langsung seperti memberi daftar pertanyaan untuk dijawab.

\subsection{Jenis Penelitian Data}

Adapun jenis dan sumber data yang digunakan dalam penulisan penelitian ini antara lain sebagai berikut :

\section{Data Kuantitatif}

Adalah data yang dinyatakan dalam bentuk angka. Merupakan hasil dari perhitungan dan pengukuran, sebagai contoh: tinggi badan, umur, jumlah benda, atau penghasilan seseorang yang dapat dihitung atau data yang berupa angka-angka meliputi penjualan.

2. Data Kualitatif 
Adalah data yang diperoleh dari hasil wawancara dengan pihak-pihak yang berkepentingan berupa data lisan dengan penjelasan mengenai pembahasan..

\subsection{Perancangan Diagram Blog Pada Load Cell}

Dalam perancangan Diagram blok. berfungsi untuk mengetahui jalannya suatu proses rangkaian kelistrikan Load cell, dan merupakan salah satu bagian terpenting dalam perancangan karena dari diagram blok dapat diketahui prinsip kerja keseluruhan rangkaian.

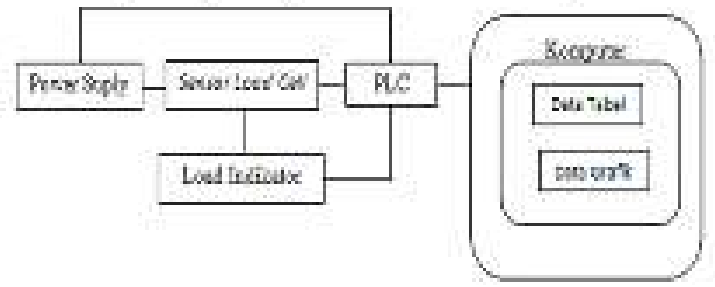

Gambar 3.1 Diagram Blok Rangkaian

\subsection{Flowchart alat pengukuran berat benda load cell}

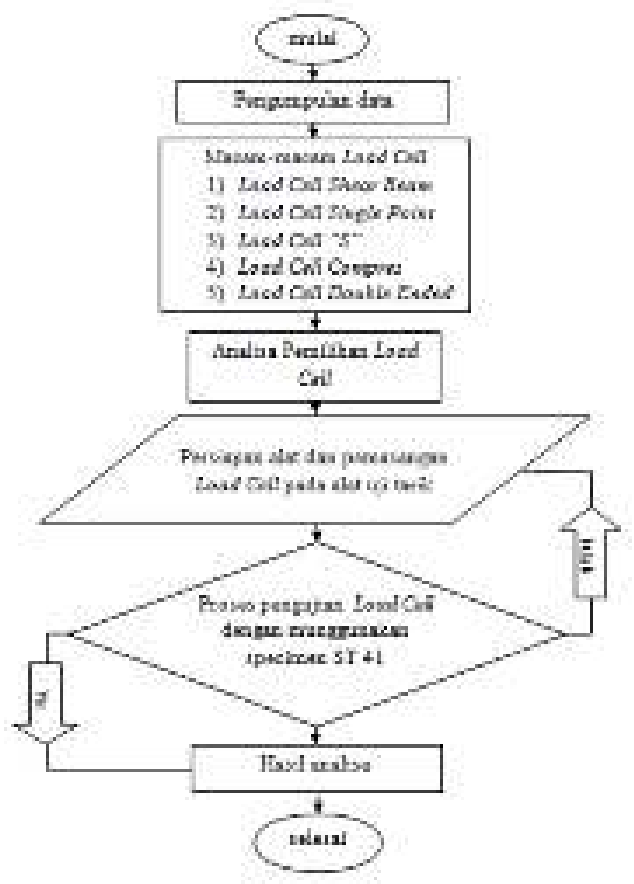

Gambar 3.2 Flowchat

\section{HASIL DAN PEMBAHASAN}

\subsection{Data hasil uji tarik}

Data yang diambil dari hasil pengujian di BPPT sebagai master dalam merancang alat uji tarik kapasitas 3 ton, dan specimen yang diuji adalah ST 41, ST 41 adalah specimen yang akan kita gunakan sebagai specimen yang akan diuji dalam untuk rancang alat uji tarik kapasitas 3 ton,

Tabel 4.1 Hasil Pengujian Di BPPT

\begin{tabular}{|c|c|c|c|c|c|c|c|c|c|c|c|}
\hline \multirow{2}{*}{$k$} & 8 & $v$ & b & I. & \multicolumn{2}{|c|}{ Bs } & & & $t$ & \multirow{2}{*}{ ist. } & \multirow{2}{*}{ Q $A$} \\
\hline & $t$ & $x^{\prime}$ & Es & $\theta$ & 10 & sty & $1-\pi^{8}$ & $d x^{\prime}$ & $\xi$ & & \\
\hline : & 趾 & 53 & $x$ & $\because$ & K & ie: & 8 & tr: & z & w & 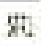 \\
\hline 2 & 迢 & $\because 6$ & $!$ & 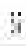 & 19? & ; & et & $i \beta i$ & 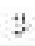 & $\mathscr{3}$ & 25 \\
\hline 3 & $z^{*}$ & $\$ 5$ & I & : & (5) & $12 i$ & \&: & 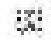 & $\ddot{i}$ & $\mathbb{2}$ & 界: \\
\hline
\end{tabular}

Keterangan : Ao = Luas penampang,

$\mathrm{Fu}=$ Beban tarik, $\sigma_{0,2 \%}=$ Kuat luluh

$\mathrm{F}_{0,2 \%}=$ Beban lulu, $\varepsilon=$ Elongasi $\quad \sigma_{\mathrm{u}}=$

Kuat tarik

\subsection{Data hasil uji tarik dari rancangan alat uji tarik LAB TM-18}

Data yang diambil dari hasil rancangan alat uji tarik dalam perbandingan kekuatan alat uji tarik

Tabel 4.2 Hasil Rancangan Alat Uji Tarik

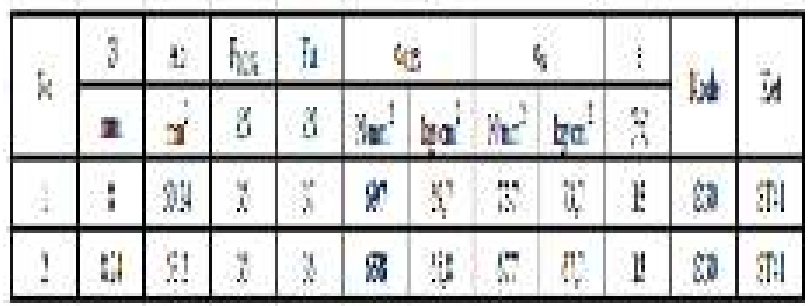

Keterangan :Ao $=$ Luas penampang, $\quad \mathrm{Fu}=$ Beban tarik, $\sigma_{0,2} \%=$ Kuat luluh, $\mathrm{F}_{0,2 \%}=$ Beban lulu, $\varepsilon=$ Elongasi, $\sigma_{\mathrm{u}}=$ Kuat tarik

Dalam pengujian specimen ST 41 peneliti melakukan dua tes specimen dengan diameter 8 $\mathrm{mm}$ dan $8.24 \mathrm{~mm}$, perbandinag ini untuk mengetahui "Berapa kekuatan maksimum dan pertambahan panjang dari spesimen ST41" liat pada digram kekuatan tarik dibawah ini 


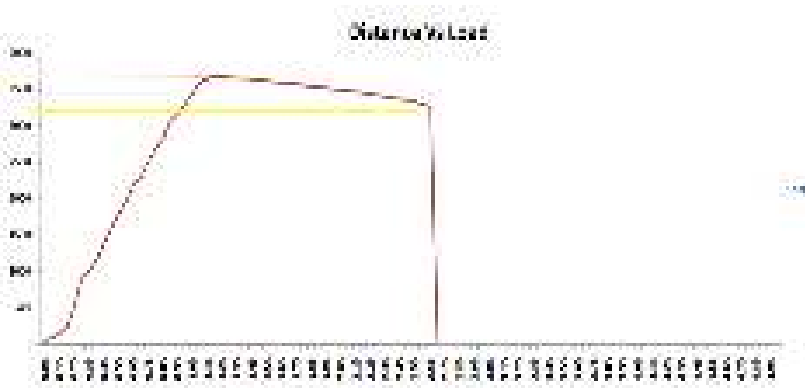

\section{Gambar 4.3 Diagram Pengujian Specimen ST} 41

Maka dari itu dapat kita liat berapa kekuatan maksimum dari specimen ST 41 :

$$
\text { Dik: } \begin{aligned}
D & =8,24 \mathrm{~mm} \\
F_{\mathrm{o}} & =35 \mathrm{kN} \\
\mathrm{F}_{\mathrm{u}} & =37 \mathrm{kN} \\
\mathrm{L}_{\mathrm{o}} & =38 \mathrm{~mm}
\end{aligned}
$$

Dit : $\quad F_{\max \ldots \ldots . . . . . ?}$

$$
F_{y} \ldots \ldots \ldots \ldots . . . . . ?
$$$$
\varepsilon \text {.............? }
$$

1. Luas penampang

$$
\begin{aligned}
& \mathrm{A}=\frac{\pi \cdot d^{2}}{4} \\
& \mathrm{~A}=\frac{3.14 .8 \cdot 24^{2}}{4} \\
& \mathrm{~A}=53.2 \mathrm{~mm}^{2}
\end{aligned}
$$

2. Regangan

$$
\begin{aligned}
\sigma_{02 \%} & =\frac{F o}{A} \\
\sigma_{02} \% & =\frac{35.000 \mathrm{~N} / \mathrm{mm}^{2}}{53.2 \mathrm{~mm}^{2}} \\
\sigma_{02 \%} & =658 \mathrm{~N}
\end{aligned}
$$

3. Tegangan

$$
\begin{aligned}
\sigma_{\max } & =\frac{\mathrm{Fu}}{A} \\
\sigma_{\max } & =\frac{36.000 \mathrm{~N} / \mathrm{mm}^{2}}{53.2 \mathrm{~mm}^{2}} \\
\sigma_{\max } & =677 \mathrm{~N}
\end{aligned}
$$

\section{Elongasi}

$$
\begin{aligned}
\varepsilon & =\frac{\Delta \mathrm{L}}{\mathrm{Lo}} \times 100 \% \\
\varepsilon & =\frac{5 \mathrm{~mm}}{38 \mathrm{~mm}} \times 100 \% \\
\varepsilon & =13 \%
\end{aligned}
$$

\subsection{Pembahasan}

Dari apa yang kita bahas dalam judul Analisa pemilihan load cell pada alat uji tarik kapasitas 3 Ton dapat kita ketahui, bahwa setiap load cell memiliki masing-masing fungsi tersendir dalam pengoprasiannya begitu pula pemilihan load cell untuk rancang bangun alat uji tarik kapasitas 3 ton, yang dimana dalam pemilihan load cell ini dari 5 jenis load cell yang berbeda 4 diantaranya adalah load cell tekan dan 1 load cell tarik, dalam perancangan membuat alat uji tarik maka load cell yang dipilih adalah load cell tarik yaitu load cell "S" dalam pengujian ST 41dengan kekuatan tariknya yaitu $3000 \mathrm{~kg}$ oleh sebab itu load cell yang kita pilih adalah load cell dengan kapasitas $5000 \mathrm{~kg}$. Untuk menunjang keamanan dalam pengoprasiannya.

\section{KESIMPULAN DAN SARAN}

\subsection{Kesimpulan}

Selama proses kegiatan dalam membuat laporan tugas akhir (penelitian). Peneliti membahas analisa Load cell alat uji tarik kapasitas 3 ton. Dari hasil penelitian dan pembahasan tentang alat uji tarik, penulis mengambil beberpa kesimpulan diantaranya

1. Pada pemilihan load cell bertujuan untuk memilih kecocokan dalam rancangan alat uji tarik kapasitas 3 ton, oleh karena itu dari 5 jenis load cell yang mendekati rancangan alat uji tarik adalah jenis load cell " $S$ " cara menggunakannnya load cell ini adalah dengan menarik bagian sisi atas dan bawahnya. Bagian sisi atas diletakkan pada tempat permanen, sedangakan untuk bagian bawahnya digunakan untuk objek atau material yang akan diukur. Material atau specimen yang kita uji adalah ST 41 dengan kekuatan tarik $3000 \mathrm{~kg}$ oleh karena itu dalam pemilihan load cell juga bertujuan untuk 
memilih kapasitas yang akan digunakan, kapasitas load cell yang kita pakai adalah $5000 \mathrm{~kg}$ untuk menghindar dari hal-hal yang tidak kita inginkan seperti permasalah mekanik dan zero balance

2. Masalah yang sering kali terjadi pada Load Cell. terjadi berbagai macam kondisi dan penyebabnya, seperti kerusakan mekanikal, electrical, atau bedasarkan lingkungan sekitar. Berikut ini permasalahannya yang sering diperbincangkan, yaitu penyebab kerusakan system antara lain;
a) Permasalahan mekanik
b) Kondisi lingkungan
c) Pengecekan fisik
d) Zero balance

\subsection{Saran}

Pada akhir dari bagian karya tulis ini, saya akan menyampaikan saran-saran dari apa yang kita bahas diatas. Dan dalam pembuatan konstruksi alat uji tarik ini tentunya tidak terlepas dari beberapa kekurangan. Kekurangan itu baik dalam konstruksi maupun pemilihan material atau komponen untuk membuat mesin uji tarik. Dan ini beberapa saran perbaikan.

1) Perlu adanya modifikasi pada chuck untuk meningkatkan faktor keamanan pada saat spesimen mau diuji.

2) Hasil yang tertera pada computer hanya angka kekuatan tariknya saja.

3) belum bisa memprogram Monitor untuk menampilkan data Grafik .

4) load indikator masih belum bisa berhenti pada saat specimen putus. Dan angka akan kembali dimana ketitik nol.

5) Kapasitas load cell yang kita gunakan adalah $5000 \mathrm{~kg}$ atau 5 ton. Dalam laporan ini kita menggunkan 3 ton. Dan batas min 1 dan mak 4

6) Tidak menggunakan specimen uji tarik melebihi kapasitas load cell pada mesin alat uji tarik yaitu melebihin $5000 \mathrm{~kg}$ atau 5 ton

Jamaludin oleh karena itu Semoga laporan ini bermanfaat bagi kita semua dan membangun gagasan pemikiran yang positip. Berupa keritik dan saran yang sifatnya untuk membangun laporan penelitian ini untuk lebih sempurna.

\section{DAFTAR PUSTAKA}

Adhitya Chandra Wijaya, 2011, Rancang Bagun Alat Uji Bending Dan Hasil Pengujian Untuk Bahan Kuningan, Penelitian, Jurusan Teknik Fakultas Teknik Mesin, Semarang.

Engkos Koswara, Perancangan Mesin Uji Tarik Dengan Menggunakan Load Cell 100 kg , Fakultas Teknik Universitas Majalengka

Handy Wicaksono, 2009, Programmable Logic Controller Teori Pemrograman Dan Aplikasinya Dalam Otomasi Sistem. Graha ilmu. Yogyakarta.

Haris Budimans, Analisis Pengujian Tarik (Tensile Tets) Pada Baja ST 37 Dengan Alat Bantu Ukur Load Cell, Jurusan Teknik Fakultas Teknik Mesin Universitas Majalengka, Vol 03 No 1 Noverber 2016

Slamet Mualif, 2012, Pembuatan Alat Uji Tarik Material, Program Fisika Fakultas Matematika Dan Ilmu Pengetahuan Alam, Depok

Try Utami Hidayani,Tri Miharani, Abdul Rahman, Dedy Hermanto, Rancangan Bangun Timbangan Buah Digital Dengan Keluaran Berat Dan Harga, Teknik Komputer

Wahyu Setyo Pambudi. Imam Suhendra, Perbaikan Respon Output Menggunakan Implementasi Kalman Filter Pada Simulasi Pembacaan Sensor Beban Load Cell, Makalah Teknik Elektro, Universitas Internasional Batam, October 2015.

Artikel - raja load cell 5 jenis load cell dan cara menggunakannya- 
www.rajaloadcell.com/articel/5-jenis$\underline{\text { load-cell-dan-cara-menggunakannya- }}$ $\underline{123}$

Web site berita indonesia - Teori dasar load cell - jumat, 14 febuari 2013- http://www.expose.web.id/2013/02/teo ri-dasar-load-cell.html

web site - Load Cell Hand Book www.rlws.com 